\title{
Hubungan Body Mass Index dengan Laju Aliran Saliva (Studi pada Mahasiswa Fakultas Kedokteran Gigi Universitas Andalas)
}

\author{
Fildzah Nurul Fajrin*, Zulkarnain Agus ${ }^{* *}$, dan Nila Kasuma*** \\ *Program Studi Pendidikan Dokter Gigi, Fakultas Kedokteran Gigi, Universitas Andalas, Padang, Sumatera Barat, Indonesia \\ **Departemen Gizi, Fakultas Kedokteran Gigi, Universitas Andalas, Padang, Sumatera Barat, Indonesia \\ ${ }^{* * \star D}$ Departemen Oral Biologi, Fakultas Kedokteran Gigi, Universitas Andalas, Padang, Sumatera Barat, Indonesia \\ Jl Perintis Kemerdekaan No 77, Padang, Sumatera Barat, Indonesia; e-mail: nilakasuma10@gmail.com
}

\begin{abstract}
ABSTRAK
Laju aliran saliva merupakan salah satu faktor penting pembentukan karies. Laju aliran saliva yang adekuat dapat mencegah proses pembentukan karies dan perkembangan penyakit periodontal dan infeksi oral. Status gizi adalah salah satu faktor yang mempengaruhi laju aliran saliva. Salah satu parameter status gizi adalah Body Mass Index (BMI). Tujuan penelitian ini adalah untuk mengetahui hubungan antara BMI dengan laju aliran saliva. Penelitian ini merupakan penelitian observasional dengan pendekatan crosss sectional study yang dilakukan pada 24 orang mahasiswa Fakultas Kedokteran Gigi Universitas Andalas yang berumur $18-25$ tahun yang memenuhi kriteria inklusi dan eklusi. BMI ditentukan dengan rumus BMI dengan satuan $\mathrm{kg} / \mathrm{m}^{2}$. Laju aliran saliva ditentukan dengan metode Sialometry Navazesh (2008) dalam satuan $\mathrm{ml} / \mathrm{menit}$. Analisa data univariat dilakukan untuk mendeskripsikan masing-masing variabel, untuk melihat distribusi normal $(p>0,05)$ dilakukan uji normalitas Kolmogorov Smirnof test. Setelah terbukti variabel terdistribusi normal, selanjutnya dilakukan uji korelasi regresi untuk mengetahui hubungan antara BMI dengan laju aliran saliva. Berdasarkan hasil uji korelasi didapatkan rata-rata BMI mahasiswa Fakultas Kedokteran Gigi Universitas Andalas adalah $\bar{x} \bar{x}_{ \pm \mathrm{SD}}=24,50 \pm 6,02 \mathrm{~kg} / \mathrm{m}^{2}$ dan laju aliran saliva adalah $\bar{x} \bar{x} \pm \mathrm{SD}=0,29 \pm 0,10 \mathrm{ml} / \mathrm{menit}$. Hubungan antara BMI dengan laju aliran saliva menunjukkan hubungan sedang dengan arah negatif $(r=-0,451)$. Hasil uji regresi linear diketahui bahwa Laju Aliran Saliva $=0,404-0,008^{*}(B M I)$. Koefisien regresi BMI 0.008 menyatakan bahwa setiap penambahan $1 \mathrm{BMI}$ maka akan menurunkan laju aliran saliva sebanyak $0,008 \mathrm{ml} /$ menit. Penelitian ini menyimpulkan bahwa terdapat hubungan bemakna antara Body Mass Index (BMI) dengan laju aliran saliva. Pada kelompok obesity memiliki laju aliran yang lebih rendah dibandingkan individu non obese (underweight, normal weight dan overweight). Sedangkan laju aliran saliva pada kelompok underweight tidak ditemukan penurunan laju aliran saliva.
\end{abstract}

Maj Ked Gi. Ind. Desember 2015; 1(2): 156 - 162

Kata kunci: Body Mass Index, laju aliran saliva

ABSTRACT: Relationship between Body Mass Index and Saliva Flow Rate (A Study in Faculty of Dentistry, Andalas University). Saliva flow rate is an affecting factor of caries formation. Adequate saliva flow rate can prevent cariess formation process and progression of periodontal disease and oral infection. Nutritional status is known as an influencing factor of saliva flow rate. The parameter of nutritional status is Body Mass Index (BMI). The purpose of this study is to discover the relation between BMI and saliva flow rate in College Students of the Dentistry Faculty Andalas University. This observational study with cross sectional design was conducted to 24 college students of the Dentistry Faculty Andalas University whose ages were 18-25 years old who complied with inclussion and exclussion criteria. BMI was calculated with BMI formula. The saliva flow rate was determined with Sialometry Method of Navazesh 2008 with "ml/minute" unit. The univariat data analysis was caried out to describe each variable. Normality test Kolmogorov Smirnoff was done to see the normal distribution $(p>0,05)$. After the distribution was proven to be normal, corelation and regression test was executed to discover the relation between $B M I$ and saliva flow rate. Based on the correlation test result, $B M I$ of college students of the Dentistry Faculty Andalas University is $\bar{x} \bar{x} \pm S D=24,6 \pm 6,02 \mathrm{~kg} / \mathrm{m}^{2}$ and saliva flow rate is $\bar{x} \bar{x} \pm S D=0,29 \pm 0,1 \mathrm{ml} /$ minute. The relation between $B M I$ and saliva flow rate expresses medium correlation with negative direction $(r=-0,451)$. The result of linear regression shows that Saliva Flow Rate $=0,404-0,008^{*}(B M I)$. The coefficient of regression BMI 0.008 shows that increasing 1 unit of BMI will decrease saliva flow rate 0,008 ml/minute. This study concludes that there is correlation between Body Mass Index and saliva flow rate. Obesity group has the lowest saliva flow rate, while the saliva flow rate does not decrease in underweight group.

Maj Ked Gi. Ind. Desember 2015; 1(2): 156 - 162

Keywords: Body Mass Index, saliva flow rate 


\section{PENDAHULUAN}

Perubahan komponen saliva adalah salah satu faktor pembentukan karies. Perubahan karakteristik saliva dapat digunakan sebagai indikator diagnostik penyakit sistemik dan penyakit rongga mulut. Saliva berperan dalam pembentukan pelikel di permukaan gigi, adhesi bakteri, pembentukan plak, sebagai larutan pembersih, pelumas, buffer, dan reservoir kalsium dan fosfat, yang berfungsi dalam proses remineralisasi lesi karies. ${ }^{1}$ Sifat-sifat saliva yang mempengaruhi pembentukan karies yaitu laju aliran, $\mathrm{pH}$, dan kapasitas buffer saliva. ${ }^{2}$

Laju aliran saliva merupakan parameter yang menggambarkan normal, tinggi, rendah, atau sangat rendahnya aliran saliva yang dinyatakan dalam satuan $\mathrm{ml} /$ menit. $^{3}$ Apabila laju aliran saliva berkurang maka terjadilah peningkatan jumlah bakteri penyebab karies seperti Lactobacilus dan Streptococcus mutans. ${ }^{4}$ Laju aliran saliva juga berkontribusi dalam perkembangan penyakit periodontal dan infeksi oral seperti candidiasis. ${ }^{5}$ Pada individu dengan laju aliran saliva yang rendah, bacterial clearance menjadi berkurang sehingga kolonisasi bakteri periodontitis seperti Streptococcus constellatus, Eubacterium nodatum, Porphyromonas gingivalis, dan Actinobacillus actinomycetemcomitans di jaringan rongga mulut meningkat. ${ }^{6}$ Individu dengan laju aliran saliva yang rendah akan mengalami masalah medis seperti xerostomia, mucosal inflammation, burning mouth, gangguan pengecapan, demineralisasi gigi, kesulitan pengunyahan, gangguan bicara dan retensi gigi tiruan yang buruk. ${ }^{7}$ Laju aliran saliva yang rendah juga mempengaruhi dietary habit dan status gizi sehingga berakibat negatif terhadap kualitas hidup individu. Laju aliran saliva dipengaruhi oleh banyak faktor, salah satunya adalah status gizi. Status gizi yang buruk dapat mempengaruhi sekresi dan komposisi saliva sehingga menyebabkan laju aliran saliva berkurang. Salah satu parameter status gizi adalah Body Mass Index. ${ }^{8}$

Body Mass Index (BMI) adalah pengukuran statistik terhadap berat badan dan tinggi badan individu yang digunakan untuk mengklasifikasikan individu ke dalam kategori tingkatan berdasarkan berat badan. BMI terdiri dari empat kategori yaitu underweight, normal weight, overweight, dan obesity. ${ }^{9} \mathrm{BMI}$ sering digunakan sebagai alat screening untuk masalah kesehatan yang berkaitan dengan penyakit jantung, diabetes, cancer, dan karies. BMl yang rendah (underweight) menyatakan bahwa berat badan di bawah normal oleh karena asupan kalori lebih rendah daripada asupan kalori harian. BMI yang tinggi (overweight dan obesity) menunjukkan bahwa terjadi kelebihan berat badan karena asupan kalori harian lebih banyak daripada kebutuhan yang sebenarnya. ${ }^{10}$

Pannuzio (2010) menyatakan bahwa individu yang overweight dan obesitas memiliki potensi untuk mengalami xerostomia dan meningkatnya resiko karies. Penyakit periodontal yang parah juga sering terjadi pada pasien yang overweight dibandingkan individu dengan BMI normal. ${ }^{11}$ Individu underweight juga beresiko mengalami hiposalivasi dan karies. ${ }^{12}$ Perubahan-perubahan keadaan rongga mulut yang terjadi pada kategori BMI tersebut berhubungan dengan laju aliran saliva.

Penelitian mengenai BMI dengan laju aliran saliva sudah banyak dipublikasikan. Individu dengan BMI yang rendah, akan memiliki laju aliran saliva yang lebih kecil dibandingkan individu dengan BMI normal. Hal tersebut disebabkan oleh karakteristik kelenjar saliva. Inoue et al (2006) menyatakan bahwa BMI berkorelasi positif dengan ukuran kelenjar saliva. Ukuran kelenjar parotid dan submandibular pada individu underweight lebih kecil dibandingkan individu dengan BMI normal. ${ }^{13}$

Penelitian lain oleh Modeer et al (2010) menyatakan laju aliran saliva meningkat dengan bertambahnya BMI, tetapi laju aliran saliva akan berkurang pada individu yang memiliki nilai BMI yang lebih dari 25 pada sampel orang dewasa yang berumur lebih dari 50 tahun. Penelitian Flink pada tahun 2007 menunjukkan bahwa ada hubungan antara BMI dengan laju aliran saliva. ${ }^{14}$

Berdasarkan penelitian dan pentingnya pembuktian teori tentang hubungan Body Mass Index dengan laju aliran saliva yang merupakan faktor penting terbentuknya karies, penulis tertarik untuk meneliti hubungan antara BMI dengan laju aliran saliva. Tujuan dari penelitian ini adalah untuk mengetahui mengetahui hubungan BMI dengan 
laju aliran saliva. Manfaat dari penelitian ini adalah pemakaian sampel yaitu bagian dari populasi mahasiswa kedokteran gigi diharapkan penelitian ini dapat menambah khasanah ilmu dalam yaitu, membuktikan teori tentang hubungan BMI dan laju aliran saliva. Penelitian telah mendapatkan persetujuan dari Komisi Etik Fakultas Kedokteran Universitas Andalas.

\section{METODE PENELITIAN}

Subjek yang dipilih untuk penelitian ini, harus memenuhi kriteria inklusi. Subjek terlebih dahulu subjek diminta menandatangani informed consent sebagai pernyataan bersedia mengikuti penelitian, tidak makan, minum, menggosok gigi selama 1 jam sebelum pengumpulan saliva. Kemudian dilakukan pengukuran BMI pada subjek. Kemudian subjek penelitian diminta untuk berkumur perlahan dengan larutan aquadest untuk membuang debrisdebris dari rongga mulut. Dan diintruksikan untuk menelan sebanyak satu kali untuk membuang sisa air di dalam mulut, kemudian subjek diminta untuk menunggu dengan tenang selama 2 menit.

Pengumpulan saliva dilakukan pada pagi hari pukul 09.00 sampai dengan 11.00. Subjek duduk membungkuk ke depan dengan posisi rileks. Lidah diletakkan di permukaan lingual insisivus atas. Mulut subjek tetap terbuka. Saliva mengalir secara pasif ke dalam gelas ukur $5 \mathrm{ml}$ melalui funnel. Saliva dikumpulkan selama 10 menit. Laju aliran saliva ditentukan dengan skala volume dengan lama waktu pengumpulan saliva dengan satuan (ml/menit).

\section{HASIL PENELITIAN}

Rata-rata laju aliran saliva pada BMI underweight $\left(<18,5 \mathrm{~kg} / \mathrm{m}^{2}\right)$ adalah $\bar{x} \bar{x} \pm \mathrm{SD}=0,21$ $\pm 0,02 \mathrm{ml} /$ menit. Pada BMl normal weight $(18,5-$ $\left.24,9 \mathrm{~kg} / \mathrm{m}^{2}\right)$, rata-rata laju aliran saliva adalah $\bar{x} \bar{x}$ $\pm \mathrm{SD}=0,29 \pm 0,13 \mathrm{ml} /$ menit. Pada BMl overweight $\left(25-30 \mathrm{~kg} / \mathrm{m}^{2}\right)$, rata-rata laju aliran saliva adalah $\bar{x}$ $\bar{x} \pm \mathrm{SD}=0,18 \pm 0,07 \mathrm{ml} /$ menit. Pada BMl obesity $\left(>30 \mathrm{~kg} / \mathrm{m}^{2}\right)$, rata-rata laju aliran saliva adalah $\bar{x} \bar{x} \pm$ $\mathrm{SD}=0,15 \pm 0,04 \mathrm{ml} /$ menit.

Tabel 1. Distribusi Rata-Rata Laju Aliran Saliva berdasarkan BMI

\begin{tabular}{lcccc}
\hline Variabel & Mean & SD & $95 \% \mathrm{Cl}$ & $p$ \\
\hline BMI & & & & \\
& & & $0,19-$ & 0,032 \\
$<18,5 \mathrm{~kg} / \mathrm{m}^{2}$ & 0,21 & 0,02 & 0,24 & \\
$18,5-24,9$ & 0,29 & 0,13 & $0,19-$ & 0,41 \\
$\mathrm{~kg} / \mathrm{m}^{2}$ & & & $0,11-$ & \\
$25-30 \mathrm{~kg} /$ & 0,18 & 0,07 & 0,24 & \\
$\mathrm{~m}^{2}$ & & & $0,09-$ & \\
$>30 \mathrm{~kg} / \mathrm{m}^{2}$ & 0,15 & 0,04 & 0,21 & \\
\hline
\end{tabular}

Hasil uji statistik didapat nilai $p=0,032$, berarti pada $\alpha=95 \%$ dapat disimpulkan ada perbedaan laju aliran saliva diantara keempat tingkatan BMI. Analisis korelasi-regresi dilakukan untuk melihat hubungan lebih lanjut antara BMI dengan laju aliran saliva.

Tabel 2. Hasil Analisis Hubungan Body Mass Index dengan Laju Aliran Saliva

\begin{tabular}{ccccc}
\hline Variable & R & R2 & Persamaan Garis & $P$ \\
\hline Laju Aliran & $-0,451$ & 0,203 & LAS $=0,404-$ & 0,027 \\
Saliva & & & $0,008^{*}(\mathrm{BMI})$ & \\
\hline
\end{tabular}

Dari Tabel 2. dapat dilihat bahwa hasil analisis uji statistik menggunakan uji korelasi Pearson pada penelitian ini didapat nilai korelasi Pearson (r) sebesar $-0,451$ yang menunjukkan hubungan sedang dengan tarif signifikansi $(p) 0,027(p<0,05)$. Dari hasil analisis uji statistik tersebut dapat disimpulkan bahwa terdapat hubungan yang bermakna antara BMI dengan laju aliran saliva.

Nilai koefisien dengan determinasi 0,203 artinya $20,3 \%$ dari variasi variabel dependent (laju aliran saliva) yang dapat dijelaskan oleh variabel independent (Body Mass Index) sedangkan sisanya sebesar 0,797 atau $79,7 \%$ (1- 0,506 atau 100\% $50.6 \%$ ) dijelaskan oleh variabel-variabel lain di luar variabel yang ada. Hubungan Body Mass Index dengan laju aliran saliva dapat dilihat di Gambar 1. 


\section{laju aliran saliva (ml/menit)}

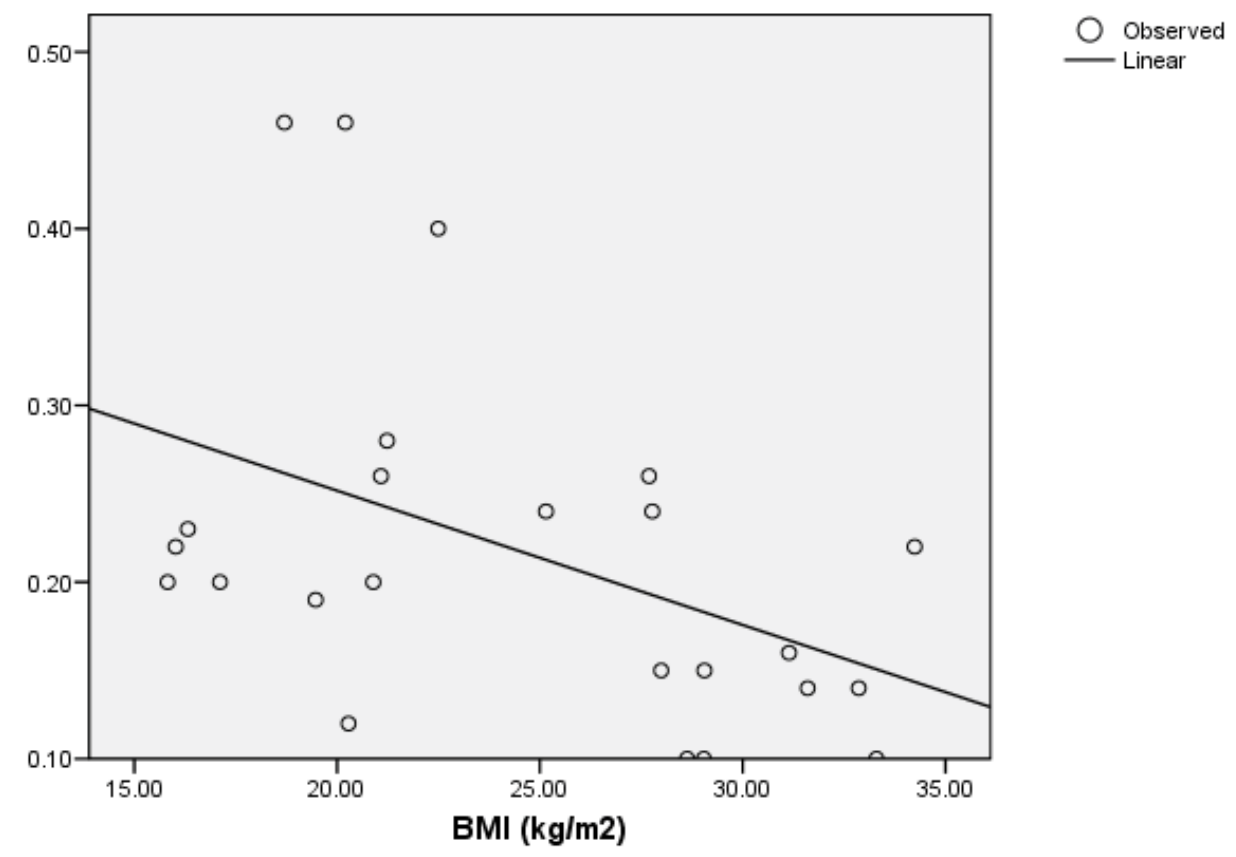

Gambar 1. Analisis Korelasi dan regresi BMI dengan Laju Aliran Saliva

Hubungan antara BMI dengan laju aliran saliva menunjukkan arah korelasi negatif dan kekuatan korelasi sedang $(r=-0,451)$ dengan $p<0,05$, yang artinya semakin bertambah BMI maka laju aliran saliva akan semakin rendah. Hasil uji regresi linear diketahui bahwa Laju Aliran Saliva $=0,404-0,008^{*}$ (BMI). Koefisien regresi BMI 0.008 menyatakan bahwa setiap penambahan 1 BMI maka akan menurunkan laju aliran saliva sebanyak $0,008 \mathrm{ml} /$ menit.

\section{PEMBAHASAN}

Hasil uji statistik pada penelitian ini menunjukkan bahwa hubungan yang bermakna antara Body Mass Index dengan laju aliran saliva $(p<$ $0,05)$. Hubungan antara BMI berkekuatan sedang dengan arah negatif yang artinya semakin besar BMI maka akan semakin rendah laju aliran saliva. Laju aliran saliva bernilai normal pada subjek underweight dan normal weight, dan menurun pada subjek overweight dan obesity. Subjek obesity memiliki nilai laju aliran saliva yang paling rendah dibandingkan tiga kelompok BMI lainnya.

Perubahan komponen saliva adalah salah satu faktor pembentukan karies. Perubahan karakteristik saliva dapat digunakan sebagai indikator diagnostik penyakit sistemik dan penyakit rongga mulut. Laju aliran saliva merupakan salah satu karakteristik saliva yang berperan dalam pembentukan karies. ${ }^{2}$ Individu dengan laju aliran saliva yang rendah akan mengalami masalah medis seperti xerostomia, mucosal inflammation, burning mouth, gangguan pengecapan, demineralisasi gigi, kesulitan pengunyahan, gangguan bicara dan retensi gigi tiruan yang buruk. ${ }^{7}$

Laju aliran saliva dipengaruhi oleh banyak faktor, salah satunya adalah status gizi. Status gizi yang tidak normal dapat mempengaruhi sekresi dan komposisi saliva sehingga menyebabkan laju aliran saliva berkurang. Status gizi dapat dinyatakan dengan parameter yaitu BMI. ${ }^{9}$

Penelitian cross sectional tentang hubungan laju aliran saliva dan karies pada subjek overweight, obesity, dan non obese pernah dilakukan oleh Baydaa et al (2011) di Baghdad pada 35 orang sampel dewasa yang berumur 30-40 tahun. ${ }^{15}$ Dinyatakan bahwa terdapat penurunan laju aliran saliva yang signifikan pada subjek obesitas dan overweight dibandingkan subjek non obese. Ratarata laju aliran saliva pada sampel non obese (BMI 
$<25 \mathrm{~kg} / \mathrm{m}^{2}$ ) adalah $\bar{x} \bar{x} \pm \mathrm{SD}=0,48 \pm 0,25 \mathrm{ml} /$ menit, sedangkan rata-rata laju aliran saliva pada sampel overweight (BMI $\geq 25 \mathrm{~kg} / \mathrm{m}^{2}$ sampai dengan $<30$ $\mathrm{kg} / \mathrm{m}^{2}$ ) adalah $\bar{x} \bar{x} \pm \mathrm{SD}=0,47 \pm 0,19 \mathrm{ml} /$ menit dan sampel obesity $\left(\mathrm{BMI}>30 \mathrm{~kg} / \mathrm{m}^{2}\right)$ adalah $\bar{x} \bar{x} \pm \mathrm{SD}=$ $0,43 \pm 0,18 \mathrm{ml} / \mathrm{menit}$.

Flink (2007) melakukan penelitian cross sectional pada 1427 orang yang berumur 20 sampai dengan 69 tahun yang memiliki BMI $>25 \mathrm{~kg} / \mathrm{m}^{2}$ di Swedia Utara tentang prevalensi penurunan laju aliran saliva yang berhubungan dengan kesehatan umum, karies, dan efek suplementasi zat besi. Dinyatakan bahwa hubungan BMI dengan laju aliran saliva adalah signifikan. Prevalensi penurunan laju aliran saliva yang berhubungan dengan BMI ditemukan pada individu yang berumur kurang dari 50 tahun. Flink menyatakan bahwa terdapat penurunan laju aliran yang bermakna terhadap usia. ${ }^{8}$

Penelitian case control yang dilakukan oleh Modeer et al (2010) di Swedia dengan sampel sebanyak 65 orang obesitas yang berumur 11 sampai 18 tahun tentang hubungan obesitas dengan laju aliran saliva dan karies pada remaja, ${ }^{14}$ didapatkan bahwa terdapat penurunan laju aliran saliva secara signifikan pada individu obesitas dibandingkan kelompok kontrol. BMI berhubungan dengan laju aliran saliva secara signifikan $(p<$ $0,001)$. Rata-rata laju aliran saliva pada sampel obesitas adalah $\bar{x} \bar{x} \pm \mathrm{SD}=1,2 \pm 0,5 \mathrm{ml} /$ menit, sedangkan pada kelompok kontrol adalah $\bar{x} \bar{x} \pm \mathrm{SD}$ $=2,0 \pm 0,9 \mathrm{ml} /$ menit.

Mozaffari et al (2012) melakukan penelitian eksperimental di Indianapolis, Indiana pada tikus Zucker jantan obesitas dan tikus jantan kurus sebagai kelompok kontrol yang diberi asupan diet nonkariogenik. ${ }^{16}$ Kelenjar saliva diamati dengan Micro Computed Tomography (Micro-CT) selama 6 minggu sampai 6 bulan. Hasil pengamatan yang dilakukan oleh Mozaffari menunjukkan bahwa tikus Zucker obesitas memiliki lebih banyak lemak di kelenjar saliva dibandingkan kelompok kontrol. Penurunan laju aliran saliva disebabkan oleh deposit lemak di sekitar kelenjar saliva. Penumpukan lemak tersebut memicu produksi sitokin yang mempengaruhi abnormalitas fungsi kelenjar saliva sehingga laju alir saliva berkurang. Hal ini didukung oleh penelitian Modeer et al (2010) yang menyatakan bahwa pada individu obesitas terjadi peningkatan jumlah adypocytes di jaringan parenkim kelenjar saliva. ${ }^{14}$ Proinflammatory cytokines yang berasal dari adipocyte dan makrofag menumpuk di jaringan adiposa. Hal ini akan menyebabkan chronic low-grade inflammation yang mempengaruhi fungsi kelenjar saliva.

Hubungan BMI dengan laju aliran saliva dengan pola negatif yaitu semakin tinggi BMI maka akan semakin rendah laju aliran saliva. Penelitian ini menunjukkan bahwa individu obesity memiliki laju aliran saliva yang lebih rendah dibandingkan individu non obese (underweight, normal weight, dan overweight).

Hasil penelitian kohort dilakukan Psoter et al (2008) yang dilakukan pada 1017 orang yang berusia 11 - 19 tahun di Haiti menyatakan bahwa laju alir saliva menurun secara signifikan pada individu underweight. ${ }^{17}$ Laju alir saliva pada individu normal adalah $\bar{x} \bar{x} \pm \mathrm{SD}=1,05 \pm 0,60 \mathrm{ml} / \mathrm{menit}$, sedangkan pada individu underweight adalah $\bar{x}$ $\bar{x} \pm \mathrm{SD}=1,02 \pm 0,63 \mathrm{ml} / \mathrm{menit}$, dan pada individu underweight dengan malnutrisi adalah $\bar{x} \bar{x} \pm \mathrm{SD}=$ $0,93 \pm 0,58 \mathrm{ml} / \mathrm{menit}$. Pada individu underweight yang memiliki riwayat childhood malnutrition mengalami penurunan laju alir saliva sebanyak $0,03 \mathrm{ml} /$ menit. Keadaan ini disebabkan oleh malnutrisi post natal kronis yang mempengaruhi pertumbuhan kelenjar saliva. Malnutrisi pada usia anak-anak yang berlanjut ke usia dewasa akan menyebabkan penurunan laju aliran saliva.

Sedangkan laju aliran saliva pada kelompok underweight pada penelitian ini tidak sejalan dengan penelitian sebelumnya, terbukti adanya hubungan yang bermakna antara Body Mass Index dengan laju aliran saliva, namun pada individu underweight tidak ditemukan penurunan laju aliran saliva. Hal ini dapat dipengaruhi oleh halhal lain yang dapat menstimulus sekresi saliva. Keterbatasan pada penelitian ini penuaan dan skor plak tidak dimasukkan dalam kriteria penelitian. Takeuchi et al (2015) menyatakan bahwa penuaan dan skor plak sangat berpengaruh pada penurunan laju alir saliva. ${ }^{18}$ 


\section{KESIMPULAN}

Dari hasil penelitian dapat disimpulkan bahwa terdapat hubungan yang bermakna antara Body Mass Index dengan laju aliran saliva. Pada kelompok obesity memiliki laju aliran yang lebih rendah dibandingkan individu non obese (underweight, normal weight dan overweight). Sedangkan laju aliran saliva pada kelompok underweight tidak ditemukan penurunan laju aliran saliva.

\section{SARAN}

Berdasarkan hasil penelitian diketahui hubungan antara Body Mass Index dengan laju aliran saliva dengan pola negatif yaitu semakin besar BMI maka laju aliran saliva semakin lambat. Oleh karena itu, individu yang memiliki BMI overweight dan obesity disarankan untuk lebih memperhatikan oral hygiene karena beresiko mengalami penurunan laju aliran saliva. Perlu dilakukan penelitian lebih lanjut dalam pemeriksaan laju aliran stimulated saliva untuk melihat hubungan antara Body Mass Index dengan laju aliran stimulated saliva.

\section{DAFTAR PUSTAKA}

1. Hegde, Mithra N, Suchetha Kumari, Nidarsh Hegde, Anu Moany. Correlation between total antioxidant level and dental caries in adults - an in vivo. Study Research Journal of Pharmaceutical, Biological and Chemical Sciences 2. 2011; 4: $864-870$.

2. Mori F, Noriko H, Masayuki O, Junji T. Effect of mastication on flow and properties of saliva. Asian Pac J Dent. 2012; 12: 1-5.

3. Almeida, Patricia DV, Ana MTG, Maria ANM, Antonio ASDL, Luciana RA. Saliva composition and functions: a comprehensive review. The Journal of Contemporary Dental Practice. 2008; 9: 1-11.

4. Pannuzio E, Olga MSA, Maria SDSV, Douglas NDS, Fausto MSM, José N. Analysis of the stimulated whole saliva in overweight and obese school children. Rev Assoc Med Bras. 2010; 56: 32-6.
5. Hopcraft MS, Tan C. Xerostomia: an update for clinicians. Australian Dental Journal. 2010; 55: 238-244.

6. F.R.Telles, R.P.Telles, A.Sachdeo, N.G.Uzel, X.Q.Song, G.Torressyap, M.Singh. Comparizon of microbiology changes in early re-developing biofilm on natural teeth and dentures. J. Periodontal. 2012; 8: 1139-1148.

7. Alves, Cresio, Marcia B, Juliana A, Rafaela $M$. Use of graduated syringes for measuring salivary flow rate: a pilot study. Braz Dent J. 2010; 21: 401-404.

8. Flink H. Studies on the prevalence of reduce salivary flow rate in relation to general health and dental caries, and effect of iron supplementation . Karolinska Institutet Stockholm. 2007.

9. WHO. Body mass index - BMI; 2012 [diakses pada November 2013]. dapat dilihat di: http:// www.euro.who.int/en/health-topics/diseaseprevention/nutrition/a-healthy lifestyle/bodymass-index-bmi

10. Hooley M, Helen S, Cecile B, Julie S, Nicky K. Body mass index and dental caries in children and adolescents. a systematic review of literature published 2004 to 2011. Sistematic Review 2012 volume 1; 2012 [diakses pada November 2013. Dapat dilihat di: http://www. systematicreviewsjournal.com/content]

11. Saito T, Shimazaki $Y$, Kiyohara $Y$, Kato I, Kubo M, Lida M, Yamashita Y. Relationship between obesity, glucose tolerance, and periodontal disease in Japanese women: the Hisayama study. 2005; 40: 346-353.

12. Köksal, Eda, Meryem Tekçiçek, Sıddıka Songül Yalçın, Belma Tuğrul, Suzan Yalçın, Gülden Pekcan. Association between anthropometric measurements and dental caries in turkish school children. Cent Eur $\mathrm{J}$ Public Health. 2011; 19:147-151.

13. Inoue $\mathrm{H}$, Ono $\mathrm{K}$, Masuda $\mathrm{W}$, Morimoto Y, Tanaka T, Yokota M, Inenaga K. Gender difference in unstimulated whole saliva flow 
rate and salivary gland sizes. Arch Oral Biol. 2006; 51: 1055-1060.

14. Modéer, Thomas, Cecilia CB, Biniyam W, Annika J, Claude M. Association between obesity, flow rate of whole saliva, and dental caries in adolescents. 2010; 18: 2367-2373.

15. BaydaaAY. The relation of salivary antioxidants to dental caries among overweight and obese adult age $30-40$ years old at textile factory in mosul city. J Bagh College Dentistry. 2011; 23: 142-143.

16. Mozaffari, Mahmood, Rafik A, Ibrahim Z, Mohammed ES, Jun YL, Hereward W,
Ahmed EM. Submandibular gland and caries succeptabity in the obese zucker rat. J Oral Pathol Med. 2012.

16. Psoter, Walter J, Andrew LS, Ralph V. Effect of childhood malnutrition on salivary flow and pH. Arch Oral Biol. 2008; 53: 231-237.

17. Takeuchi K, Furuta M, Takeshita T, Shibata Y, Shimazaki $Y$, Akifusa S, Ninomiya T, Kiyohara Y, Yamashita Y. Risk factors for reduced salivary flow rate in a japanese population. The Hisayama Study: Biomed Research International; 2015. [diakses pada 23Januari 2016]. Dapat di lihat di http://dx.doi. org/10.1155/2015/381821 